\title{
Management of Leaf Rust of Wheat through Different Levels of NPK and Sowing Times
}

\author{
Muhammad Atiq ${ }^{1, *}$, Nazir Javed ${ }^{1}$, Sidra Urooj ${ }^{1}$, Aftab Ali Bukhari ${ }^{1}$, Yasir Ali ${ }^{1}$, Ahmad Zeeshan ${ }^{2}$, \\ Amna Shahid ${ }^{1}$, Shafqat Ali ${ }^{1}$, Abdul Jabbar ${ }^{3}$, Wasi-ud-Din ${ }^{3}$ \\ ${ }^{1}$ Department of Plant Pathology, University of Agriculture, Pakistan \\ ${ }^{2}$ Department of Plant Pathology, University College of Agriculture, University of Sargodha, Pakistan \\ ${ }^{3}$ Department of Agronomy, University of Agriculture, Pakistan
}

Copyright $(2017$ by authors, all rights reserved. Authors agree that this article remains permanently open access under the terms of the Creative Commons Attribution License 4.0 International License

\begin{abstract}
Leaf rust (Puccinia triticina f. sp. tritici) is universal threat for wheat production. In present study, effect of sowing dates $\left(30^{\text {th }}\right.$ Oct; $10^{\text {th }}, 20^{\text {th }}$ and $30^{\text {th }}$ Nov) and NPK levels (N1-80Kg, N2-100Kg, N3-60Kg, $\mathrm{P}_{1}-58 \mathrm{Kg}, \mathrm{P}_{2}-70 \mathrm{Kg}$, $\mathrm{P}_{3}-50 \mathrm{Kg}, \mathrm{K}_{1}-63 \mathrm{Kg}, \mathrm{K}_{2}-75, \mathrm{~K}_{3}-55 \mathrm{Kg}$ ) against leaf rust and their impact on 1000 grain were evaluated under Randomized Complete Block Design (RCBD) at Plant Pathology research area in University of Agriculture Faisalabad during 2009. Results showed that among 3 fertilizers, $\mathrm{K}$ exhibited significant result as compared to N, P and control for management of leaf rust and produced maximum 1000 grain weight. Among sowing dates, rust severity was minimum in early sown $\left(30^{\text {th }}\right.$ Oct) and maximum in late sown ( $\left.30^{\text {th }} \mathrm{Nov}\right)$. Thus early sowing with different levels of NPK has paramount importance to combat leaf rust severity effectively.
\end{abstract}

Keywords Leaf Rust, Severity, Sowing Date, Wheat, Yield

\section{Introduction}

Wheat is a vital cereal crop of the $1 / 3^{\text {rd }}$ of world's and it is being consumed as staple food [16]. To meet human demands for wheat in 2050, $2 \%$ annual increase in wheat production is compulsory on the same cultivated area [56]. It supplies $72 \%$ calories and protein in the average diet [10]. In Pakistan, an area of 9,062 thousand hectares is under cultivation with 23,421 thousand tonnes annual production and having $2,585 \mathrm{~kg} \mathrm{ha}^{-1}$ average yield. However, the production is highly constrained by rusts which cause losses to wheat are remarkable [31]. Leaf rust (Lr) (Puccinia triticina f.sp. tritici) is globally distributed and the peak disparaging wheat crop foliar disease and wheat production can be jeopardized by this disease especially in favorable conditions [19]. According to Saari [44], leaf rust is cosmopolitan in distribution and is considered an unremitting dilemma. $\mathrm{Lr}$ of wheat is a threat in most of wheat growing areas of Pakistan owing to prolonged season for its development and the time of appearance [53]. Lr pathogen is prolific in nature that retains numerous physiological races [24]. These races have different level of virulence and are capable of infecting various wheat cultivars [34]. In Pakistan, several times epidemic form of this disease has appeared [9]. Neglecting the other vagaries which lower the production of wheat, $L r$ alone can cause 30 to 50 percent yield losses under favorable environment. Rust epidemic history indicates impact of this disease [7]. Yield losses up to 40 to $50 \%$ have been recorded in different parts of the world [33]. This loss in yield is influenced by the time of infection and disease intensity [4] or more responsible by the resistance level, and maturity stage of crop when initial infection occurs [28, 29]. In case of early onset of rust, grain yield losses in susceptible cultivars may exceed $50 \%$ [59].

Sowing time of wheat have prime importance to get maximum yield and manage the leaf rut disease [12] because Puccinia recondite, the causal agent of leaf rust required particular environmental conditions for its survival and spread [26]. Disease resistance in crops is genetically controlled. However, natural disease resistance mechanisms can be enhanced by plant nutrients [35]. Use of balanced fertilizers is a necessary requirement for the best management strategies to increase yield per acre as well as for the control of many plant diseases [51]. Adequate supply of nutrition (NPK) to the crop is reduced the $L r$ and increased the yield of wheat $[11,15]$.

Keeping in view these above facts, present study was designed to investigate different levels of NPK and sowing times for the management of leaf rust of wheat and their impact on yield. 


\section{Material and Methods}

\section{Effect of Sowing Dates on Leaf Rust and Thousand Grain Weight of Wheat}

Universal rust spreader "Morocco" was sown in different sowing dates to optimize date of sowing in response to the rust development. Experiment was conducted at four different sowing dates, early $\left(30^{\text {th }}\right.$ October $)$, mid $\left(10^{\text {th }}\right.$ November), late $\left(20^{\text {th }}\right.$ and $30^{\text {th }}$ November). Data was recorded on the basis of rust severity, area under Leaf Rust Progress Curve (AULRPC) [47] on each sowing date under natural rust inoculum pressure and its effect on 1000-grain weight was observed.

\section{Evaluation of Different Levels of NPK for Wheat Leaf Rust Management}

Different doses of fertilizers (N, P, and K) were applied to find out their effect against leaf rust. Spring wheat cultivar "Morrocco" was planted in 2-4 meters strips. The wheat cultivar (Morocco) was chosen for study because it is highly susceptible to races of Puccinia triticina. Planting was done during moth of October and November 2009. All fertilizers were used at sowing time. Nitrogen in form of urea, Phosphorus in form of triple superphosphate and Potash in form of murate of potash were applied in three replications. These fertilizers were tested at three different doses namely, recommended dose, $\left(\mathrm{N}_{1}, \mathrm{P}_{1}, \mathrm{~K}_{1}\right)$, above then recommended $\left(\mathrm{N}_{2}, \mathrm{P}_{2}, \mathrm{~K}_{2}\right)$ and below recommended dose $\left(\mathrm{N}_{3}, \mathrm{P}_{3}, \mathrm{~K}_{3}\right)$ of each fertilizer $\left(\mathrm{N}_{1}-80 \mathrm{Kg}, \mathrm{N}_{2}-100 \mathrm{Kg}, \mathrm{N}_{3}-60 \mathrm{Kg}, \mathrm{P}_{1}-58 \mathrm{Kg}\right.$, $\mathrm{P}_{2}-70 \mathrm{Kg}, \mathrm{P}_{3}-50 \mathrm{Kg}, \mathrm{K}_{1}-63 \mathrm{Kg}, \mathrm{K}_{2}-75, \mathrm{~K}_{3}-55 \mathrm{Kg}$ ) for an area of one hectare. The "Morrocco" plants were inoculated in the early boot stage. One $\mathrm{ml}$ spore suspension $\left(2 \mathrm{X} 10^{5}\right.$ urediniospores per $\mathrm{ml}, 0.02 \%$ Tween 20 ) was injected into the randomly selected plant stems [36]. To ensure the appearance of disease, two sprays of inoculum were also done [48]. Field was irrigated to produce optimum humidity which is necessary for the rust development $[14,20]$. The plot without any fertilizer application $\left(\mathrm{N}_{\mathrm{o}}, \mathrm{P}_{\mathrm{o}}, \mathrm{K}_{\mathrm{o}}\right)$ in each replication served as a control. Effect of fertilizers (NPK) on Lr severity was recorded by using the modified Cobb's scale [38] and 1000 grain weight was recoded.

\section{Statistical Data Analysis}

The trial was laid according to the Randomized Complete Block Design (RCBD). All statistical tests performed using SAS/STAT statistical software [46]. Means were separated using Fisher's protected significant difference (LSD) procedure.

\section{Results}

Maximum disease severity was observed on wheat sown on $30^{\text {th }}$ of November (AULRPC $=623$ ) followed by the wheat sown at $20^{\text {th }}$ November $($ AULRPC $=435)$ and wheat sown on $10^{\text {th }}$ of November (AULRPC $=345$ ) while minimum was observed on the wheat sown on $30^{\text {th }}$ October $($ AULRPC $=218)$ (Fig. 1). Effect of four sowing dated in response to $L r$ on thousand grain weight was calculated. Minimum thousand grain weight (34.2) was recorded during late sown at $30^{\text {th }}$ November, while its value was maximum (37.1) in early sown $30^{\text {th }}$ October (Fig. 2).

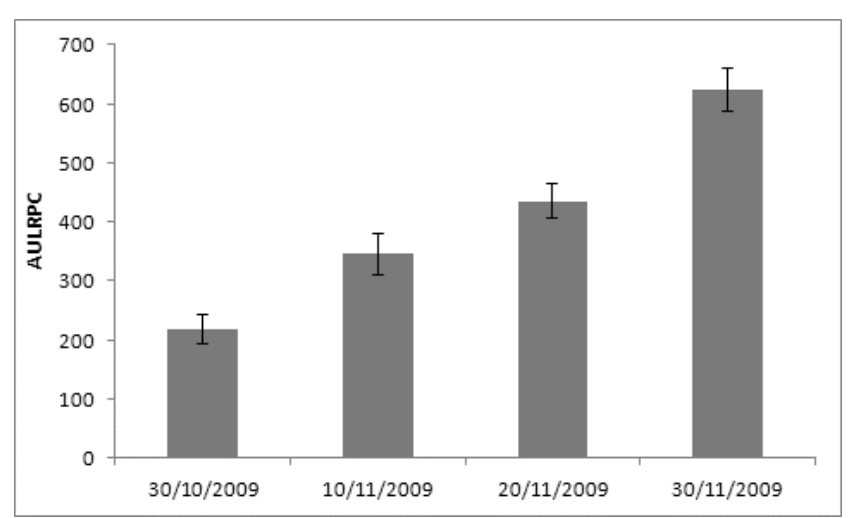

Figure 1. Effect of Sowing Dates on Leaf Rust Severity and Their AULRPC

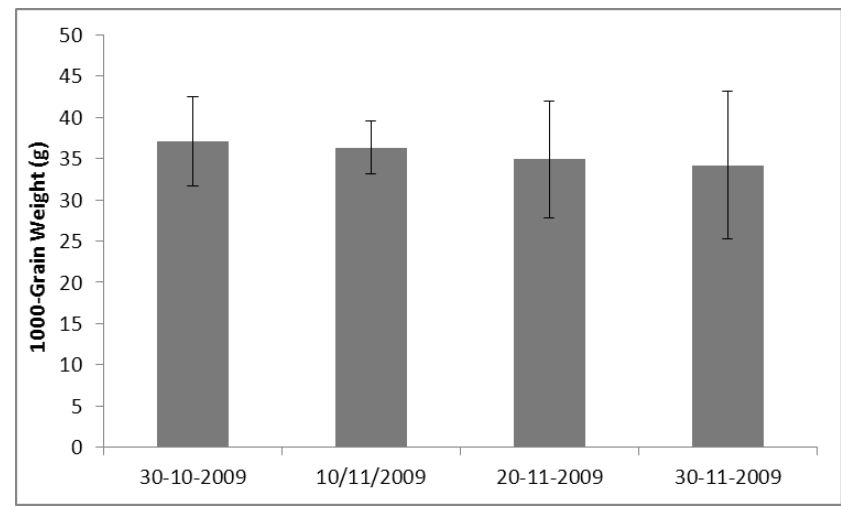

Figure 2. Thousand Grain Weight of Wheat Sown At Different Sowing Dates in Response to Wheat Leaf Rust

Three Nitrogen doses with one control $\left(\mathrm{N}_{0^{-}} 0, \mathrm{~N}_{1}-80 \mathrm{Kg}\right.$, $\mathrm{N}_{2}-100 \mathrm{Kg}, \mathrm{N}_{3}-60 \mathrm{Kg}$,) were used against leaf rust in the field trial for testing their effectiveness. All the doses of nitrogen except treatment $\mathrm{N}_{1}$ statistically increased $\mathrm{Lr}$ severity as compared to control. Maximum $\operatorname{Lr}$ severity (65) was observed in treatment $\mathrm{N}_{2}$ followed by $\mathrm{N}_{3}(55)$ and $\mathrm{N}_{1}(43.33)$ respectively (Fig. 3). All the doses of nitrogen improved 1000-grain weight over check. Maximum 1000-grain weight $(32.60 \mathrm{~g})$ was obtained in case of treatment $\mathrm{N}_{1}$ (Fig. 4). The least effective treatment was proved to be $\mathrm{N}_{2}$ which gave less weight of 1000 -grains $(31.60 \mathrm{~g})$. In case of phosphorus treatment $\mathrm{P}_{2}$ expressed maximum reduction in diseases severity (41.66) as compared to $\mathrm{P}_{1}(55), \mathrm{P}_{3}$ (46.66) and control (Fig. 5). Maximum yield of 1000-grain weight was obtained in case of $\mathrm{P}_{2}$ (35.53 g) and $\mathrm{P}_{3}$ gave (30.83g) (Fig. 6). 


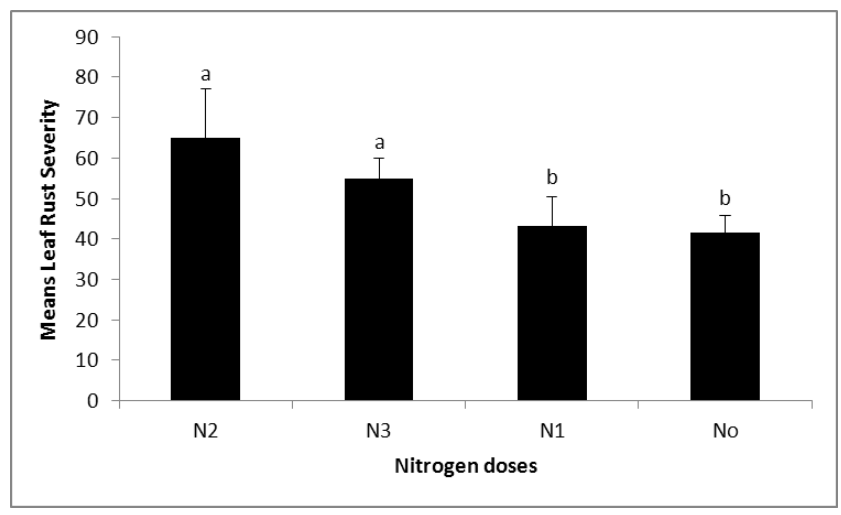

Figure 3. Effect of Different Nitrogen Doses on Mean Leaf Rust Severity.

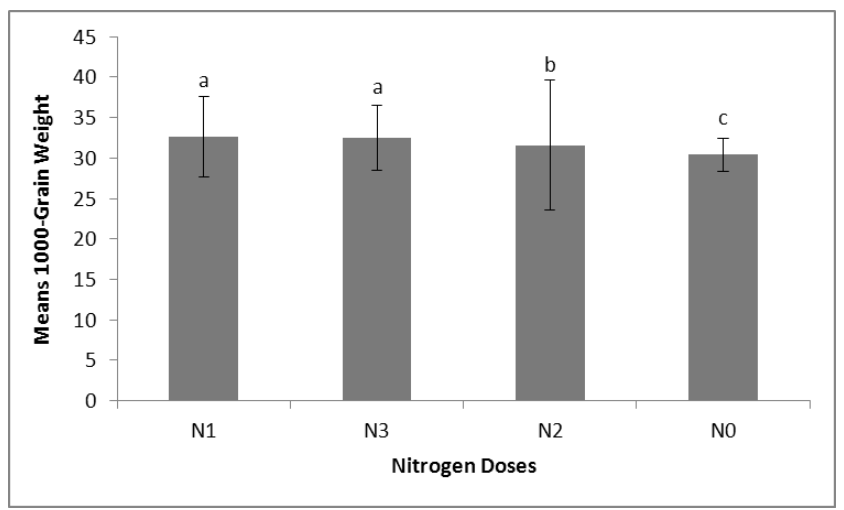

Figure 4. Effect of Different Doses of Nitrogen on Mean 1000-Grain Weight $(\mathrm{g})$.

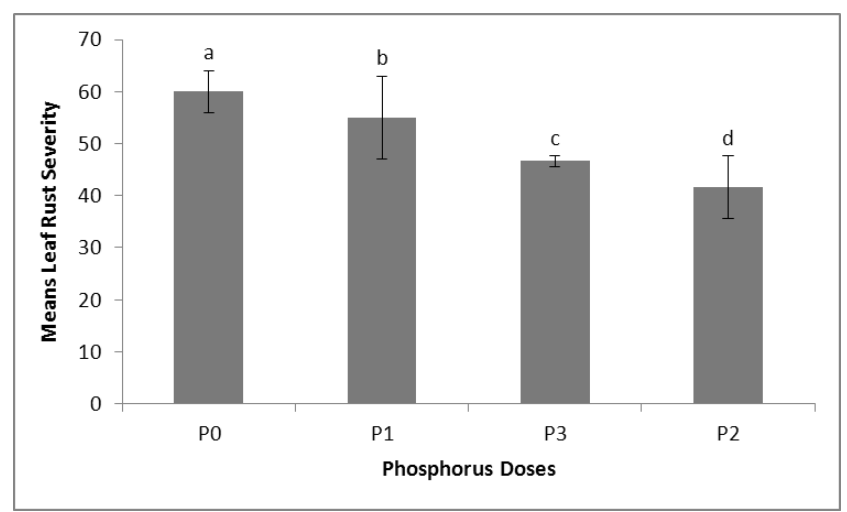

Figure 5. Effect of Different Doses of Phosphorus on Mean Leaf Rust Severity

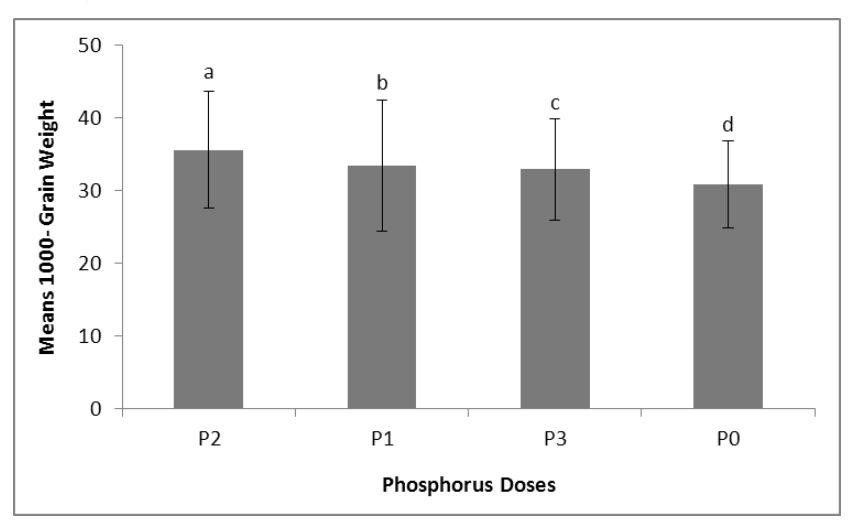

Figure 6. Effect of Different Doses of Phosphorus on Mean 1000- Grain Weight (g).
Potassium significantly reduced the $L r$ severity and increased 1000 grain weight compared to control. Maximum reduction in disease severity was observed in treatment $\mathrm{K}_{1}$ (38.33) and minimum reduction in rust severity was observed in case of $\mathrm{K}_{3}$ (45.0) (Fig. 7) Maximum yield was obtained in case of treatment $\mathrm{K}_{2}$ which gave mean 1000 -grain weight as $36.50 \mathrm{~g}$ while the least effective treatment was $\mathrm{K}_{3}$ gave mean 1000 -grain weight as $34.93 \mathrm{~g}$ (Fig. 8).

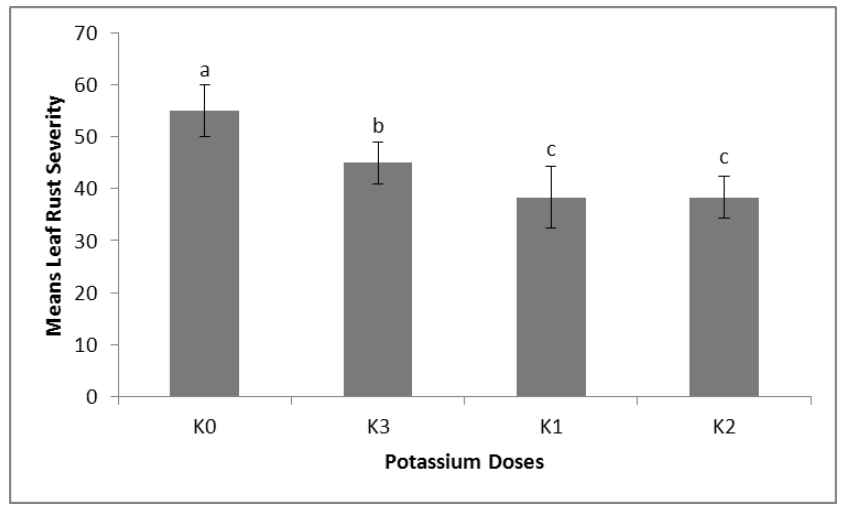

Figure 7. Effect of Different Doses of Potassium on Mean Leaf Rust Severity

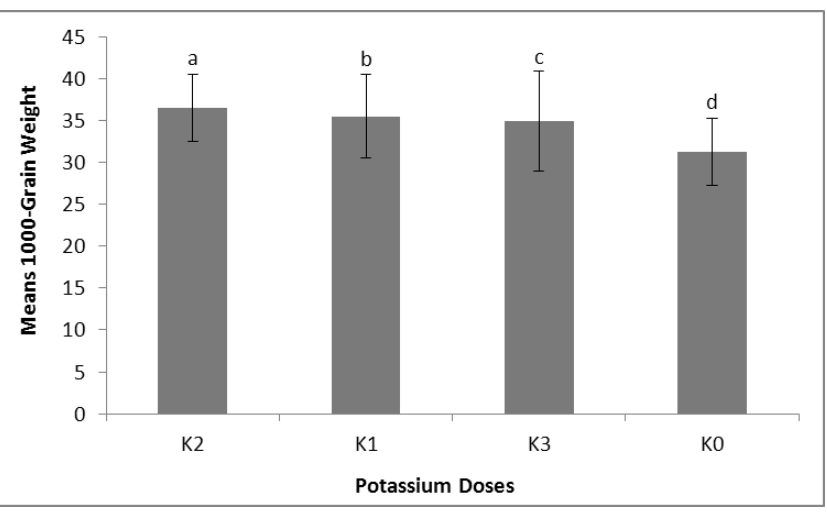

Figure 8. Effect of Different Doses of Potassium on Means 1000- Grain Weight (g).

\section{Discussion}

Wheat is cereal crop of Pakistan and have vital place in Agriculture [54]. For obtaining the highest yield as well as ameliorate the ill the effect of diseases, crop sowing at its ideal time is necessary [39]. In the sowing dates trial, disease severity was maximum (AULRPC $=623$ ) for wheat sown on the $30^{\text {th }}$ of November while minimum $($ AULRPC $=435)$ for wheat sown on the $30^{\text {th }}$ October. Grain weight was the most affected yield component. Negative correlation was observed between disease severity and 1000 grain weight. Yield losses were maximum for wheat sown on $30^{\text {th }}$ November (34.2) and minimum for wheat sown on $30^{\text {th }}$ October (37.1). Yield losses increased with late sowing [17, 45] because the temperature (maximum and minimum) and 
the amount of moisture are the lifesaver for Puccinia recondita on wheat (Triticum aestivum L.). Abnormally high temperatures or inadequate rain may inhibit establishment of volunteer wheat plants after harvest which stops or reduces survival of previous crop P. recondita inoculum [26]. Late sowing $\left(30^{\text {th }}\right.$ November) of wheat crop decreased the germination count $\mathrm{m}^{-2}$ due to temperature fluctuation which ultimately reduced the 1000 grain weight [45].

Disease resistance in crops is genetically controlled. However, natural disease resistance mechanisms are enhanced by plant nutrients [18]. Use of balanced fertilizers is necessary to increased $\mathrm{ha}^{-1}$ yield and to control plant diseases [1, 22, 35] because nutrients can interrupt the disease development by disturbing pathogen/ plant physiology [32]. Nutrients level can alter the biochemistry, physiology and especially the cell walls integrity, the host chemical composition and membrane leakage.

Nitrogen is an important fertilizer and is essential for cellular components [23]. High nitrogen dose increased the rust severity. Normally $\mathrm{N}$ fertilizers increased plant diseases due to its high use. But nitrogen at recommended $\left(\mathrm{N}_{1}\right)$ rate $\left(80 \mathrm{kgha}^{-1}\right)$ reduced the disease severity by affecting cellulose formation in plants which ultimately reduce the pathogen multiplication [25] while other treatments $\left(\mathrm{N}_{2}\right.$ and $\mathrm{N}_{3}$ ) increased the leaf rust [21, 4351,55$]$ because over dose of nitrogen promote succulent growth and thinner the cell walls making plant more susceptible to diseases. At high /low $\mathrm{N}$ rates the metabolism of the plant changes as some key enzymes of phenol metabolism have lower activity, the content of the phenolic decreases and the lignin content may be lower. So, defense system of the plants became weak and disease severity increased $[8,57]$ but all doses of $\mathrm{N}\left(\mathrm{N}_{1}, \mathrm{~N}_{2}\right.$, $\mathrm{N}_{3}$ ) improved 1000-grain weight over check [43].

All the treatments of "Phosphorus" reduced $L r$ incidence as compared to control but maximum reduction in disease incidence was in case of $\mathrm{P}_{2}$ because it increased disease resistance by stimulating the defense system of the plants as it plays a vital role in different types of physiological and biochemical processes [27, 41, 49,60]. All the doses of "Phosphorus" statistically increased 1000 -grain weight over check $[27,60]$ but maximum yield was obtained in case of $\mathrm{P}_{2}$ $[2,27]$. Appliance of $\mathrm{P}$ or $\mathrm{K}$ reduced plant diseases directly by different ways; i) by affecting pathogen metabolism, survival and development, ii) by creating hindrance in food supply to pathogen by affecting internal metabolism of the plant, and iii) by disturbing the mode of survival and spread of the pathogen by changing the cell-wall ultra-structures and functions of stomata [37].

Maximum reduction in disease severity was observed in treatment $\mathrm{K}_{1}$ while minimum in case of $\mathrm{K}_{3}$. Our results are in agreement with those of Snyder et al. [50]; Snyder and Mascagni [50] and Sweeney et al. [52]. All the doses of "Potassium" increased 1000-grain weight over check. This result is also in agreement with the findings of Ma et al. [30] who stated that 1000 -grain weight progressively increased with the application of $\mathrm{K}[3,13]$.

\section{Conclusions}

Sowing dates and different levels of NPK have a critical role in leaf rust management and 1000 grain weight of wheat. Minimum leaf rust severity was recorded on early wheat sown $30^{\text {th }}$ November.

\section{REFERENCES}

[1] G. N. Agrios. Plant diseases caused by nematodes. p. 825-874. In: Plant Pathology. 5th ed. ELSEVIER Academic press, New York, USA, 2005.

[2] S. M. Alam, S. A. Shah, S. Ali, M. M. Iqbal. Wheat yield and P fertilizer efficiency as influenced by rate and integrated use of chemical and organic fertilizer. Pakistan Journal of Soil Science. 22(2):72-76, 2003.

[3] M. R. Alam, M. R. Ali, M. S. H. Molla, M. A. Momin. M. A. Mannan. Evaluation of different levels of potassium on the yield and protein content of wheat in the high Ganges river floodplain soil. Bangladesh Journal of Agriculture Research. 34(1): 97-104, 2009.

[4] Anonymous. Effect of different rust levels on the yield of bread wheat. 535 p. Annual Report. Wheat Research Institute, Faisalabad, Pakistan, 1993.

[5] Anonymous. The State of Food and Agriculture - 2007. p. 251-252. Food and Agriculture Organization of the United Nations. Rome, 2007.

[6] Anonymous. Economic Survey of Pakistan 2008-2009. p. 18-23. Ministry of Finance. Govt. of Pakistan, 2009.

[7] N. E. Borlaug. Wheat breeding and its impact on world food supply. Third International Wheat Genetics Symposium, 5-9 August, Canberra, Australia, 1968.

[8] E. G. Brauckmann. The influence of silicic acid on mildew infection of cereals with different nitrogen fertilizers. Phytopathology. 30: 112-115, 1957.

[9] M. H. Chaudhry, M. Hussain, A. S. Shah. Wheat rust seenario.1994-95. Pakistan Journal of Phytopathology. 8: 96-100, 1996.

[10] CIMMYT. Wheat Research and Development in Pakistan. Pakistan Agriculture Research Council /CIMMYT Collaborative Programme, 1989.

[11] B. M. Cunfer, J. T. Touchton, J. W. Johnson. Effects of phosphorus and potassium fertilizations on Septoria glume blotch of wheat. Phytopathology. 70:1196-1199, 1980.

[12] W. M. Dabre, S. B. Lall, G. L. Lngole. Effects of sowing dates on yield, ear number, stomatal frequency and stomatal index in wheat. Journal of Maharashtra agricultural universities. 18:64-66, 1993

[13] B. S. Dwivedi. Response of wheat (Triticum aestivum), potato (Solanum tuherosuin) and Indian mustard (Brassica juncea) to varying particle size of potassium applied through muriate of potash. The Indian Journal of Agriculture Science. 71(10): 634-638, 2001 
[14] M. G. Eversmeyer, C. L. Kramer, L. E. Browder. Effect of temperature and host: parasite combination on the latent period of Puccinia recondita in seedling wheat plants. Phytopathology. 70: 938-941, 1980.

[15] P. E. Fixen. Crop responses to chloride fertilizers. p. 107-150. In D. L. Sparks (ed) Advances in Agronomy. Academic Press, Inc. San Diego, California, U.S.A. 1993.

[16] FAO. What is conservation Agriculture? FAO CA website.(http://www.fao.org/ag/ca/la.html), FAO, Rome. 2014.

[17] W. Getaneh, C. M. Agu. Yield loss due to leaf rust on barley at different sowing dates. Plant Science Research. 1(2): 40-43, 2008.

[18] R. D. Graham, M. J. Webb. Micronutrients and disease resistance and tolerance in plants. p. 329-370. In J.J. Mortvedt et al. (eds.) Micronutrients in Agriculture. $2^{\text {nd }}$ edition. Soil Science Society of America, 1991.

[19] S. F. Hassan. Wheat diseases situation in Pakistan. p: 6-9. Paper Presented in National Seminar on wheat research and production, 1979.

[20] W. H. Hogg, C. E. Houmam, A. K. Mallik, J. C. Zadoks. Meteorological factors affecting the epidemiology of wheat rusts. 143 p. Technical Note, 99. Geneva, Switzerland: World Meterological Organisation, 1966.

[21] D. M. Huber. The role of mineral nutrition in defense. p. 381-406. In: J.G. Horsfall and E.B. Cowling (Eds.), Plant Disease, An Advanced Treatise, Volume 5, How Plants Defend Themselves. Academic, New York, USA, 1980.

[22] D. M. Huber, R. D. Graham. The role of nutrition in crop resistance and tolerance to disease. p. 205-226. In: Rengel Z. (Ed.), Mineral Nutrition of Crops Fundamental Mechanisms and Implications. Food Product Press, New York, USA, 1999.

[23] D. M. Huber, I. A. Thompson. Nitrogen and plant disease. p. 31-44. In: Datnoff, Elmer and Huber (eds.). Mineral Nutrition and Plant Disease. APS Press, St. Paul, MN, 2007.

[24] C. O. Johnston, L. E. Browder. Seventh revision of international register of physiologic races of Puccinia recondita f.sp. tritici. Plant Disease 50: 756-760, 1966.

[25] J. Katan. Research Findings: Mineral Nutrient Management and Plant Disease. Optimizing Crop Nutrition 21:6-8, 2009.

[26] M. A. Khan, S. M. Khan, M. Hussain. Evaluation of wheat lines/varieties against artificial and natural inoculum of Puccinia recondita f.sp. tritici causing brown rust. Pakistan Journal of Agriculture Science. 39(3):226-231, 2002.

[27] R. Khan, A. R. Gurmani, A. H. Gurmani, M. S. Zia. Effect of phosphorus application on wheat and rice yield under wheatrice system. Sarhad Journal of Agriculture. 23(4):851-856, 2007.

[28] J. A. Kolmer. Physiologic specialization of Puccinia triticina in Canada in 1998. Plant Disease. 85: 155-158, 2001.

[29] J. Q. Liu, J. A. Kolmer. Inheritance of leaf rust resistance in wheat cultivars Grandin and CDC Teal. Plant Disease. 81:505-508, 1997.

[30] A. G. Ma, Z. L. Zhan, P. Zhen, L. P. Fan. The effect of potassium fertilizer in super high yield wheat fields. Journal of Henan Agriculture Science. 9: 24-25, 1999.

[31] C. N. Marasas, M. Smale, R. P. Singh. The Economic Impact in Developing Countries of Leaf Rust Resistance Breeding in CIMMYT Related Spring Bread Wheat. Economics Program Paper 04-01. Mexico, D.F. CIMMYT, 2004.

[32] H. Marschner. Mineral Nutrition of Higher Plants. 889 p. $2^{\text {nd }}$ ed. Academic, London, 1995.

[33] D. Marshall. Characteristics of the 1984-1985 wheat leaf rust epidemic in central Texas. Plant Disease 72: 239-241, 1988.

[34] S. K. Nayar, M. K. Menon, S. Nagarajan, P. Bahadur, S. B. Singh. Occurrence of new virulent pathogenic forms in race 77 of Puccinia recondita f.sp. tritici in India. Current Science. 56: 844-848, 1987.

[35] I. Oborn, A. C. Edwards, E. Witter, O. Oenema, K. Ivarsson, P. J. A. Withers, S. I. Nilsson, A. R. Stinzing. Element balances as a tool for sustainable nutrient management: a critical appraisal of their merits and limitations within an agronomic and environmental context. European Journal of Agronomy. 20: 211-225, 2003.

[36] J. K. Pataky, M. A. Campana. Reduction in common rust severity conferred by the Rp1D gene in sweet corn hybrids infected by mixtures of Rp1D-virulent and avirulent Puccinia sorghi. Plant Disease. 91:1484-1488, 2007.

[37] S. Perrenoud. Potassium and Plant Health, $2^{\text {nd }}$ ed. International Potash Institute, Bern, Switzerland (IPI Research Topics No. 3), 1990.

[38] R. F. Peterson, A. B. Campbell, A. B. Hanna. 1948. A diagrammatic scale for estimating rust severity on leaves and stems of cereals. Canadian Journal of Research (26): 249-250.

[39] W. F. Pfender. Effect of autumn planting date and stand age on severity of stem rust in seed crops of perennial ryegrass. Plant Disease. 88: 1017-1020, 2004.

[40] PPI. Effects of potassium on plant diseases. p. 37-39. In: Potassium for Agriculture, Potash \& Phosphate Institute, Norcross, GA, 1998.

[41] PPI. Phosphorus nutrition improves plant disease resistance. $p$. 26-27. In Phosphorus for Agriculture, Potash \& Phosphate Institute, Norcross, GA, 1999.

[42] A. Razzaq, P. Shah, Sartaj, B. Khan, K. Saeed, D. Mohammad. Effect of planting times on the growth and straw yield of wheat varieties. Sarhad Jornal of Agriculture. 2(2):327-334, 1986.

[43] C. M. Rush, G. Piccinni, R. M. Harveson. Agronomic measures. In: N.A. Rechcigel and J.E. Rechcigel (eds.), Environmentally Safe Approaches to Crop Disease Control. CRC Publications, Boca Raton, FL, 1997.

[44] E. E. Saari. Rust problems and how to fight them. 82-89 p. In: M. Tahir (ed.) Wheat research and production in Pakistan. Pakistan Agricultural Research Council, Islamabad, Pakistan, 1978.

[45] H. Salazar, F. J. Figueroa, P. Lopez, R. P. Singh. Estimation of potential losses caused by (Puccinia recondita) on wheat in Southren Sonora. Revista Mexicana, fitopathologia 11(1):41-46, 1992.

[46] SAS institute, INC. SAS/STAT User's Guide, Release 6.07, vol. 1. SAS Institute Inc., Cary, NC, 1990. 
[47] G. Shanner, R. E. Finnery. The effect of nitrogen fertilization on the expression of slow mildering resistant in Knox wheat. Phytopathology. 70: 1183-1186, 1997.

[48] A. Sheroze, A. Rashid, A. S. Shakir, S. M. Khan. Effect of Bio-Control Agents on Leaf Rust of Wheat and Influence of Different Temperature and Humidity Levels on Their Colony Growth. International Journal of Agriculture and Biology. $5(1): 83-85,2003$.

[49] C. S. Snyder, H. J. Mascagni. Phosphorus and potassium increase wheat yields and helpreduce disease damage [On-line]. Available at http://www.ipni.net/news. Int. Plant Nutrition Institute. News and Views from the Southeast Region, October, 1998.

[50] C. S. Snyder, L. O. Ashlock, P. Tacker, D. Widick. Chloride toxicity and potassium nutrition. Soybean Update, March, 1995. Uni. of Arkansas Coop. Extension Serv, 1995.

[51] E. C. Stakman, O. S. Aamodt. The effect of fertilizers on the development of stem rust of wheat. J of Agri Res. 27: 341-379, 1924.

[52] D. W. Sweeney, G. V. Granade, M. G. Eversmeyer, D. A. Whitney. Phosphorus, potassium, chloride, and fungicide effects on wheat yield and leaf rust severity. J of P1 Nutrition. 23(9): 1267-1281, 2000.

[53] M. Tahir. "Pakistan Wheat Production during 1977-78" in wheat research and production in Pakistan. PARC. pp: 199-255, 1978.
[54] M. Tahir, A. Ali, M. A. Nadeem, A. Hussain, F. Khalid. Effect of Different Sowing Dates on Growth and Yield of Wheat (Triticum aestivum L.) Varieties in District Jhang, Pakistan. Pak J of Life and Social Sci. 7(1): 66-69, 2009.

[55] D. G. Tanner, A. Gorfu, A. Taa. Fertilizer effects on sustainability in the wheat-based small-holder farming systems of Southeastern Ethiopia. Field Crops Res. 33(3):235-248, 1993

[56] H. Van Niekerk. South African wheat pool. 923-936 p. In: AP Bonjaen and WJ Angus (eds). The world wheat book. Lavoisier Publishing, Paris, 2001.

[57] J. R. Volk, R. P. Kahn, R. L. Weintraub. Silicon content of rice plants as a factor influencing the resistance to infection by the blast fungus Piricularia oryzae. Phytopathol. 48: 179-184, 1958.

[58] M. V. Wiese. Compendium of Wheat Disease. 112 p. $2^{\text {nd }}$ Edition, APS Press, The American Phytopathological Society, St. Paul, MN, USA, 1987.

[59] M. Yaqoob. Study on slow rusting and tolerance in wheat cultivars in bread lines in Pakistan. M.Sc. Thesis, University of Agriculture, Faisalabad, Pakistan, 1991.

[60] M. S. Zia M, Aslam, M. B. Baig, A. Ali. Fertility issues and fertilizer management in rice wheat system. A review. Science vision (COMSATS, Islamabad) 5(4):59-73, 2000. 